\title{
Effects of Electron Beam Irradiation on Microbial Quality of Pork Sausage Stored at Refrigeration Temperature
}

\author{
P. Deepika, R.J. Zende, D.P. Kshirsagar*, V.S. Lande, V.M. Vaidya, \\ R.N. Waghamare, R.P. Todankar and A.H. Shirke \\ Department of Veterinary Public Health and Epidemiology, Bombay Veterinary College, Parel, \\ Mumbai, India \\ *Corresponding author
}

\begin{tabular}{|c|c|}
\hline & A B S T R A C T \\
\hline Keywords & \multirow{4}{*}{$\begin{array}{l}\text { The effect of electron beam irradiation on microbiological qualities of pork sausage } \\
\text { samples stored at refrigeration temperature }\left(4^{0} \mathrm{C}\right) \text { was studied. Pork sausage samples were } \\
\text { exposed to } 3.0,3.5 \text { and } 4.5 \mathrm{KGy} \text { doses of electron beam irradiation and stored at } \\
\text { refrigeration temperature. Microbiological analysis of irradiated pork sausage samples } \\
\text { showed that Total Viable Count, } S \text {. aureus and yeast and mould counts in irradiated pork } \\
\text { sausage were ( } \leq 0.05) \text { significantly reduced with increasing irradiation dose. Inhibitory } \\
\text { effect of EB irradiation was observed on E. coli and Salmonella spp. count throughout the } \\
\text { storage period in the irradiated sausage samples. However, none of the irradiated and } \\
\text { control pork sausage samples were found to contain B. cereus, Pseudomonas spp. and } \\
\text { Listeria spp. throughout the entire storage. Results indicated that amongst all the EB } \\
\text { irradiation doses used under study, } 4.5 \mathrm{KGy} \text { was found to be more effective in reducing the } \\
\text { microbiological load when compared to other irradiation doses. }\end{array}$} \\
\hline $\begin{array}{l}\text { Electron beam, } \\
\text { Irradiation, Pork } \\
\text { sausages, Total viable } \\
\text { count }\end{array}$ & \\
\hline Article Info & \\
\hline $\begin{array}{l}\text { Accepted: } \\
\text { 28 September } 2017 \\
\text { Available Online: } \\
10 \text { November } 2017\end{array}$ & \\
\hline
\end{tabular}

\section{Introduction}

India possesses one of the largest livestock wealth in the world and a quarter of the agricultural gross domestic product is contributed by the livestock sector. The major meats consumed in India are fish, buffalo, mutton, goat, pig, and poultry. Pig as compared to other livestock species has a great potential to contribute to faster economic return to the farmers, because of certain inherent traits like high fecundity, better-feed conversion efficiency, early maturity and short generation interval.

Irradiation, as a method of meat preservation, is the most effective technology in the elimination of pathogenic microorganisms without compromising the nutritional properties and sensory quality of food. WHO (1999) reported that irradiation technology has positive effects in preventing decay and improving the safety and shelf-stability of food products. The US FDA approved irradiation for red meats and poultry to control food-borne pathogens and extend the shelf-life of products (Lim et al., 2008). Electron-beam (EB) irradiation was used to inactivate foodborne pathogens during storage and guarantee the hygienic quality of foods (Yim et al., 2015). The two most commonly used sources of irradiation are gamma rays 
(Cobalt60) and electron beams (Diehl, 1995). Gamma rays can penetrate the entire product. In contrast to gamma irradiation, electron beam irradiation uses accelerators that can generate electron beams of energy levels up to $10 \mathrm{MeV}$, which are directed to the product with a magnet (Nieto-Sandoval et al., 2000). Electron beams can penetrate products with a thickness of 2 to 4 inches. Even though electron beams are less penetrating than the gamma rays, they are thought to offer several advantages over gamma irradiation. These advantages include higher dose rate capability, no nuclear waste, and the fact that the accelerators can be switched on and off. A more important advantage is that the electron beam irradiation can be applied in a bidirectional manner in which the irradiation can come into contact with the food product from the top and bottom of the sample. This penetration can offer the advantage of a more uniform application of the irradiation, which can lead to a more effective elimination of bacteria, particularly on product surfaces (Lewis et al., 2002)

The tropical environment condition in India favours the microbiological spoilage of fresh meat and reduces its shelf-life and leads to certain economic loss. Keeping this view of limited information on electron beam irradiated meat products, the scientific study is therefore undertaken to assess its microbiological, physico-chemical and sensory evaluation of electron beam irradiated meat products in order to determine the shelflife henceforth provide safe products to consumer.

\section{Materials and Methods}

\section{Procurement of samples}

Freshly prepared ready-to-eat pork products such as pork sausages were procured from HACCP \& ISO certified processing plants. These products were packed separately in sterile low density polyethylene (LDPE) pouches, each containing $100 \mathrm{~g}$ of product, heat sealed and taken to Food Technology Division, Board of Radiation and Isotope Technology (BRIT), Sector 20, Turbhe, Navi, Mumbai for exposure to varying doses of electron beam irradiation. During entire duration of experiment, samples were maintained at chilling temperature $\left(0-4^{0} \mathrm{C}\right)$. The samples were collected on three different occasions and analysed for microbiological quality parameters.

\section{Irradiation}

Pork sausage samples were divided into 4 separate groups, of which one was kept as control and remaining three groups were exposed to 3.0, 3.5 and $4.5 \mathrm{KGy}$ doses of electron beam irradiation. For irradiation, the pouches were arranged in aluminium boxes and irradiated on both sides in a linear EB RF accelerator (Energy $5 \mathrm{MeV}$, beam power 40 $\mathrm{kW}$, EB tech., BRIT, Mumbai). The beam current was 0-4.5 mA. Irradiation was performed with a conveyer velocity of $10 \mathrm{~m} / \mathrm{min}$. Because the incident $\mathrm{EB}$ had a lower penetration power hence to enhance the effectiveness of irradiation the thickness of all the samples were kept $3 \mathrm{~cm}$. The doses used were as 0, 3.0, 3.5 and 4.5 KGy. During the irradiation treatment, chilled temperature was maintained by filling the aluminium boxes with ice packs. All the irradiated samples along with their corresponding controls were brought laboratory in the ice box and stored in the cold storage room at temperature of $0-4$ ${ }^{0} \mathrm{C}$, until further analysis

\section{Microbiological analysis}

$10 \mathrm{~g}$ of each sample was taken separately in $90 \mathrm{ml}$ of Normal Saline Solution (NSS) in the stomacher bags and was processed in stomacher (Seward Stomacher 80, Fisher Scientific, U.K.) at normal speed for $60 \mathrm{sec}$. There after ten-fold serial dilutions were 
made using $9 \mathrm{ml}$ sterile NSS up to $10^{6}$ dilutions. For evaluating total viable counts, standard pour plate technique was followed wherein $1 \mathrm{ml}$ of inoculum, each from $10^{-4}$ and $10^{-5}$ dilutions (in duplicate) was transferred separately to sterile empty petri plates in which 15-20 $\mathrm{ml}$ of molten nutrient agar having temperature around $43-45^{0} \mathrm{C}$ was poured and mixed thoroughly by rotating the plates five times clockwise and five time anticlockwise. After solidification of agar, the plates were kept for incubation at $37^{0} \mathrm{C}$ for 24-48 hours. Selective and differential media used for enumeration of Staphylococcus, E. coli, Bacillus cereus, Pseudomonas spp, yeast and mold count was carried out using plates of Baired Parker's Agar, Eosin Methylene Blue agar (EMBA), Bacillus cereus agar base, Pseudomonas isolation agar, and Sabouraud Dextrose Agar (SDA), respectively. Isolation and identification of Salmonella spp. was carried out as per BIS (1999). Isolation and identification of Listeria spp. was carried out as per the protocol in ISO (11290-1:2017).

\section{Statistical analysis}

The data was generated for different quality characteristics during the experiment were compiled and analysed by Randomized Block Design within the treatments on each day of storage by using software "WASP-Web Agree Stat Package- 2.0" developed at ICAR research complex, Goa, India.

\section{Results and Discussion}

\section{Total Viable Count (TVC)}

All the irradiated and non-irradiated (control) pork sausages stored at refrigeration temperature were analysed for the determination of microbiological quality at different time interval. The average TVC (log $\mathrm{cfu} / \mathrm{g}$ ) values observed in pork sausages irradiated at different doses and control samples stored at refrigeration temperature $(0$ $\left.4^{0} \mathrm{C}\right)$ are depicted in Table 1, 2, 3 and 4. The average TVC (log cfu/g) for the control samples on 0 day was found to be $5.59 \pm 0.12$ whereas, the average TVC (log $\mathrm{cfu} / \mathrm{g}$ ) for pork sausages irradiated with 3.0(SS1), 3.5(SS2) and 4.5(SS3) were observed as $4.48 \pm 0.14, \quad 4.06 \pm 0.10 \quad$ and $4.06 \pm 0.10$, respectively as shown in Table 2, 3 and 4 . The study indicated that there was significant $(p<0.05)$ reduction in microbiological load noticed in the irradiated pork sausage samples at respective doses used under the study. Although the count showed gradual decline it was not significant between SS2 and SS3 with the increase in irradiation dose on 0 day. Further, the decrease in TVC was dose dependent in all the products. All the control (non-irradiated) pork sausage samples completely spoiled on the $6^{\text {th }}$ day of refrigeration storage with the corresponding TVC as $(6.46 \pm 0.09)$ whereas, the pork sausage samples treated with Electron Beam irradiation at the dose rate of 3.0, 3.5 and $4.5 \mathrm{kGy}$ showed spoilage only on $15^{\text {th }}, 15^{\text {th }}$ and $29^{\text {th }}$ day of refrigeration storage, respectively with corresponding TVC $(6.17 \pm 0.08,6.08 \pm 0.06$ and $6.02 \pm 0.04)$.

\section{S. aureus count}

A significant difference $(\mathrm{p} \leq 0.05)$ was noticed among irradiated groups. There was a noticeable reduction seen after the irradiation in the $S$. aureus count but it gradually increased with storage (Figure 1).

\section{E. coli and Salmonella spp.}

E. coli was detected only in non-irradiated (control) pork sausage samples. The average E. coli count $(\log \mathrm{cfu} / \mathrm{g})$ on 0 day in control sample of sausage was found to be $2.70 \pm 0.23$ which gradually increased to $3.33 \pm 0.14$ on $9^{\text {th }}$ day after which the sample were not analysed as they were marred. 
Table.1 Average of microbiological count log (cfu/gm) and shelf life of pork sausages in control samples treated with Electron Beam Technology stored at refrigeration temperature $\left(0-4^{0} \mathrm{C}\right)$

\begin{tabular}{|c|l|c|c|c|c|}
\hline \multirow{3}{*}{ Treatments } & \multicolumn{1}{|c|}{$\begin{array}{c}\text { Parameters } \\
\text { studied }\end{array}$} & \multicolumn{4}{|c|}{$\begin{array}{c}\text { Average microbial countlog (cfu/gm) observed at } \\
\text { different refrigeration storage interval }\end{array}$} \\
\cline { 3 - 6 } & & $\mathbf{0}$ & $\mathbf{3}$ & $\mathbf{6}$ & $\mathbf{9}$ \\
\hline \multirow{5}{*}{ Control } & TVC & $5.59 \pm 0.12^{\mathrm{a}}$ & $5.96 \pm 0.10^{\mathrm{a}}$ & $6.26 \pm 0.11^{\mathrm{a}}$ & $6.46 \pm 0.09^{\mathrm{a}}$ \\
\cline { 2 - 6 } & S. aureus & $2.86 \pm 0.03^{\mathrm{a}}$ & $3.04 \pm 0.04^{\mathrm{a}}$ & $3.48 \pm 0.00^{\mathrm{a}}$ & $3.51 \pm 0.03^{\mathrm{a}}$ \\
\cline { 2 - 6 } & E. coli & $2.70 \pm 0.23$ & $3.01 \pm 0.27$ & $3.27 \pm 0.21$ & $3.33 \pm 0.14$ \\
\cline { 2 - 6 } & Salmonella spp. & Present & Present & Present & Present \\
\cline { 2 - 6 } & $\begin{array}{l}\text { Pseudomonas } \\
\text { spp. }\end{array}$ & Nil & Nil & Nil & Nil \\
\cline { 2 - 6 } & Bacillus cereus & Nil & Nil & Nil & Nil \\
\cline { 2 - 6 } & Listeria spp & Nil & Nil & Nil & Nil \\
\cline { 2 - 6 } & Yeast \& molds & $2.55 \pm 0.15^{\mathrm{a}}$ & $2.76 \pm 0.13^{\mathrm{a}}$ & $2.98 \pm 0.21^{\mathrm{a}}$ & $3.08 \pm 0.19^{\mathrm{a}}$ \\
\hline
\end{tabular}

Note: Means in the same column with the different superscript letters are significantly different $(\mathrm{P} \leq 0.05)$.

Table.2 Average of microbiological count log (cfu/gm) and shelf life of pork sausages treated with Electron Beam Technology at the dose rate of $3.0 \mathrm{KGy}$ and stored at refrigeration temperature $\left(0-4^{0} \mathrm{C}\right)$

\begin{tabular}{|c|c|c|c|c|c|c|c|}
\hline \multirow[t]{2}{*}{ Treatments } & \multirow{2}{*}{$\begin{array}{c}\text { Parameters } \\
\text { studied }\end{array}$} & \multicolumn{6}{|c|}{$\begin{array}{l}\text { Average microbial countlog (cfu/gm) observed at different refrigeration } \\
\text { storage interval }\end{array}$} \\
\hline & & $\mathbf{0}$ & 3 & 6 & 9 & 12 & 15 \\
\hline \multirow{8}{*}{$\begin{array}{c}\text { SS1 } \\
(3.0 K G y)\end{array}$} & TVC & $4.48 \pm 0.14^{b}$ & $4.67 \pm 0.14^{b}$ & $5.76 \pm 0.03^{b}$ & $5.93 \pm 0.02^{b}$ & $5.96 \pm 0.01^{\mathrm{a}}$ & $6.17 \pm 0.08^{\mathrm{a}}$ \\
\hline & S. aureus & $2.15 \pm 0.10^{b}$ & $2.36 \pm 0.10^{b}$ & $2.70 \pm 0.07^{b}$ & $2.87 \pm 0.02^{b}$ & $2.94 \pm 0.02^{\mathrm{a}}$ & $3.09 \pm 0.09^{\mathrm{a}}$ \\
\hline & Salmonella spp. & Nil & Nil & Nil & Nil & Nil & Nil \\
\hline & E. coli & Nil & Nil & Nil & Nil & Nil & Nil \\
\hline & Pseudomonas spp. & Nil & Nil & Nil & Nil & Nil & Nil \\
\hline & \begin{tabular}{|l|} 
Bacillus cereus \\
\end{tabular} & Nil & Nil & Nil & Nil & Nil & Nil \\
\hline & Listeria spp. & Nil & Nil & Nil & Nil & Nil & Nil \\
\hline & Yeast \& molds & $2.27 \pm 0.16^{\mathrm{b}}$ & $2.26 \pm 0.17^{b}$ & $2.46 \pm 0.10^{\mathrm{ab}}$ & $2.71 \pm 0.03^{\mathrm{a}}$ & $2.87 \pm 0.04$ & $2.87 \pm 0.04$ \\
\hline
\end{tabular}

Note: Means in the same column with the different superscript letters are significantly different $(\mathrm{P} \leq 0.05)$. 
Table.3 Average of microbiological count log (cfu/gm) and shelf life of pork sausages treated with Electron Beam Technology at the dose rate of $3.5 \mathrm{KGy}$ and stored at refrigeration temperature $\left(0-4^{0} \mathrm{C}\right)$

\begin{tabular}{|c|l|l|c|c|c|c|c|}
\hline \multirow{3}{*}{ Treatments } & \multirow{2}{*}{$\begin{array}{c}\text { Parameters } \\
\text { studied }\end{array}$} & \multicolumn{6}{|c|}{ Average microbial count log (cfu/gm) observed at different refrigeration storage } \\
interval
\end{tabular}

Note: Means in the same column with the different superscript letters are significantly different $(\mathrm{P} \leq 0.05)$.

Table.4 Average of microbiological count log (cfu/gm) and shelf life of pork sausages treated with Electron Beam Technology at the dose rate of $4.5 \mathrm{KGy}$ and stored at refrigeration temperature $\left(0-4^{0} \mathrm{C}\right)$

\begin{tabular}{|c|c|c|c|c|c|c|c|c|c|c|c|c|c|c|}
\hline \multirow{2}{*}{ Treatments } & \multirow{2}{*}{$\begin{array}{c}\text { Parameters } \\
\text { studied }\end{array}$} & \multicolumn{13}{|c|}{ Average microbial count log (cfu/gm) observed at different refrigeration storage interval } \\
\hline & & $\mathbf{0}$ & 3 & 6 & 9 & 12 & 15 & 17 & 19 & 21 & 23 & 25 & 27 & 29 \\
\hline \multirow{8}{*}{$\begin{array}{c}\text { SS3 } \\
(4.5 K G y)\end{array}$} & TVC & $\begin{array}{l}4.06 \pm 0 \\
.10^{\mathrm{c}}\end{array}$ & $\begin{array}{l}4.2 \pm \\
0.14^{\mathrm{c}}\end{array}$ & $\begin{array}{l}4.5 \pm \\
0.04^{\mathrm{c}}\end{array}$ & $\begin{array}{l}4.8 \pm \\
0.05^{\mathrm{d}}\end{array}$ & $\begin{array}{l}4.96 \pm \\
0.03^{\mathrm{b}}\end{array}$ & $\begin{array}{l}5.11 \pm \\
0.02^{\mathrm{b}}\end{array}$ & $\begin{array}{c}5.21 \pm \\
0.04\end{array}$ & $\begin{array}{c}5.36 \pm \\
0.01\end{array}$ & $\begin{array}{c}5.56 \pm \\
0.10\end{array}$ & $\begin{array}{c}5.64 \pm \\
0.09\end{array}$ & $\begin{array}{l}5.8 \pm \\
0.04\end{array}$ & $\begin{array}{l}5.9 \pm \\
0.02\end{array}$ & $\begin{array}{c}6.02 \pm \\
0.04\end{array}$ \\
\hline & S. aureus & $\begin{array}{l}1.95 \pm \\
0.00^{\mathrm{b}}\end{array}$ & $\begin{array}{l}2.0 \pm \\
0.10^{\mathrm{c}}\end{array}$ & $\begin{array}{l}2.1 \pm \\
0.10^{c}\end{array}$ & $\begin{array}{l}2.3 \pm \\
0.06^{\mathrm{c}}\end{array}$ & $\begin{array}{l}2.41 \pm \\
0.09^{\mathrm{b}}\end{array}$ & $\begin{array}{l}2.55 \pm \\
0.06^{\mathrm{b}}\end{array}$ & $\begin{array}{c}2.59 \pm \\
0.03\end{array}$ & $\begin{array}{c}2.68 \pm \\
0.03\end{array}$ & $\begin{array}{c}2.75 \pm \\
0.02\end{array}$ & $\begin{array}{c}2.78 \pm \\
0.02\end{array}$ & $\begin{array}{l}2.8 \pm \\
0.03\end{array}$ & $\begin{array}{c}2.96 \pm \\
0.00\end{array}$ & $\begin{array}{c}3.00 \pm \\
0.00\end{array}$ \\
\hline & Salmonella spp. & Nil & Nil & Nil & Nil & Nil & Nil & Nil & Nil & Nil & Nil & Nil & Nil & Nil \\
\hline & E. coli & Nil & Nil & Nil & Nil & Nil & Nil & Nil & Nil & Nil & Nil & Nil & Nil & Nil \\
\hline & $\begin{array}{l}\text { Pseudomonas } \\
\text { spp. }\end{array}$ & Nil & Nil & Nil & Nil & Nil & Nil & Nil & Nil & Nil & Nil & Nil & Nil & Nil \\
\hline & Bacillus cereus & Nil & Nil & Nil & Nil & Nil & Nil & Nil & Nil & Nil & Nil & Nil & Nil & Nil \\
\hline & Listeria spp. & Nil & Nil & Nil & Nil & Nil & Nil & Nil & Nil & Nil & Nil & Nil & Nil & Nil \\
\hline & Yeast \& molds & $\begin{array}{l}2.05 \pm \\
0.10^{\mathrm{b}}\end{array}$ & $\begin{array}{l}2.2 \pm \\
0.00^{\mathrm{b}}\end{array}$ & $\begin{array}{c}2.3 \pm \\
0.06^{\mathrm{b}} \\
\end{array}$ & $\begin{array}{l}2.5 \pm \\
0.07^{\mathrm{b}}\end{array}$ & $\begin{array}{l}2.61 \pm \\
0.06^{\mathrm{b}}\end{array}$ & $\begin{array}{l}2.70 \pm \\
0.05^{\mathrm{b}}\end{array}$ & $\begin{array}{c}2.75 \pm \\
0.02\end{array}$ & $\begin{array}{c}2.82 \pm \\
0.02\end{array}$ & $\begin{array}{c}2.87 \pm \\
0.02 \\
\end{array}$ & $\begin{array}{c}2.87 \pm \\
0.02\end{array}$ & $\begin{array}{l}2.9 \pm \\
0.02 \\
\end{array}$ & $\begin{array}{l}2.9 \pm \\
0.02 \\
\end{array}$ & $\begin{array}{c}3.02 \pm \\
0.03 \\
\end{array}$ \\
\hline
\end{tabular}

Note: Means in the same column with the different superscript letters are significantly different $(\mathrm{P} \leq 0.05)$. 
Fig.1 Average of S. aureus count (log cfu/gm) and shelf life of pork sausages treated with Electron Beam Irradiation at the dose rate of 3.0, 3.5 and $4.5 \mathrm{kGy}$ and stored at refrigeration temperature $\left(0-4^{0} \mathrm{C}\right)$

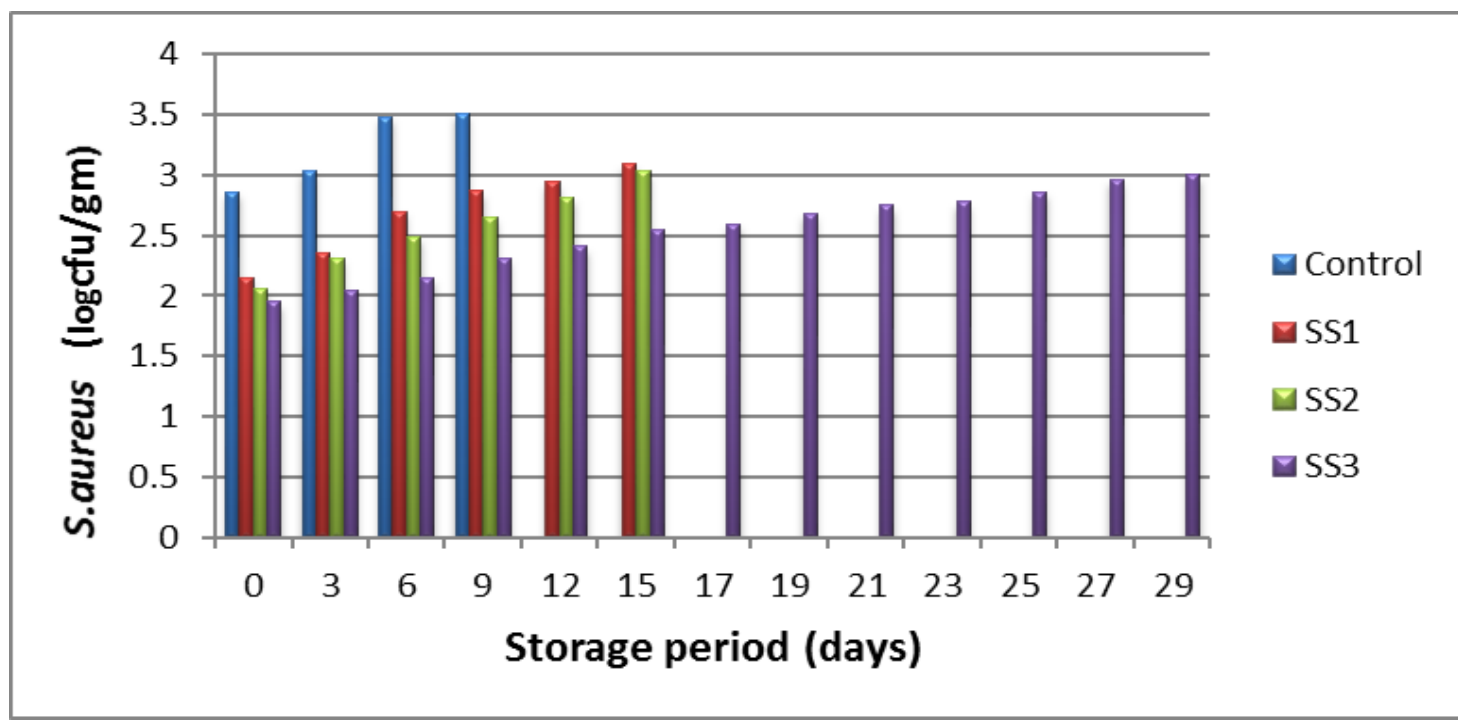

Control - Non- irradiated pork sausages, SS1- Pork sausages irradiated at the dose rate of 3.0KGy, SS2 - Pork sausages irradiated at the dose rate of $3.5 \mathrm{KGy}, \mathrm{SS} 3$ - Pork sausages irradiated at the dose rate of $4.5 \mathrm{KGy}$

However, none of the irradiated pork sausage samples were found positive for E. coli. All the control pork sausage samples showed the presence of Salmonella spp. throughout the storage up to $9^{\text {th }}$ day. However, none of the irradiated samples at different doses showed the presence of Salmonella Spp. as shown in Table 1.

\section{B. cereus, Pseudomonas and Listeria spp.}

All the control and irradiated pork sausage samples were analysed for B. cereus, Pseudomonas spp. and Listeria spp. after storage at refrigeration temperature. It was evident that from the Table 1, 2, 3 and 4 none of the pork sausage samples as well as control were found to contain these organisms.

\section{Yeast and mold count}

The increasing trend in initial yeast and mold count $(\log \mathrm{cfu} / \mathrm{ml})$ was observed in control and irradiated pork sausage samples (3.0, 3.5, and $4.5 \mathrm{KGy}$ ) from $2.55 \pm 0.15,2.27 \pm 0.16$,
$2.51 \pm 0.18$ and $2.05 \pm 0.10$ to $3.08 \pm 0.19$, $2.87 \pm 0.16,2.92 \pm 0.18$ and $3.02 \pm 0.03$ on 9,15 , 15 and 29 day of refrigeration storage, respectively.

The effectiveness of irradiation against pathogens is mainly due to hydrogen peroxide production that results from the generation of free radicals during irradiation. Hydrogen peroxide acts as a potent antimicrobial and can eventually result in the production of long-lived hypochlorite, which is very toxic to pathogens. As a result, mutations that result in loss of normal functions of the bacteria and reduce their pathogenic potential can occur (Lewis et al., 2002).

The average TVC was found to be gradually increasing in all irradiated and non-irradiated samples as storage period advanced. The results of the present study were in accordance with the findings of Niemand $e t$ al., (1981), Kim et al., (2012) and Shin et al., (2014) who reported that electron beam irradiation significantly reduced TVC in pork 
salamis and raw meat dose dependently. The shelf-life of pork salami observed under study after irradiation with $4.5 \mathrm{kGy}$ dose had shown the shelf-life of 27 days. However, Hammad et al., (2007) reported shelf life of beef salami up to 25 days after electron beam irradiation at the dose rate of $6 \mathrm{kGy}$. In contradiction to the research findings of present study pork salamis irradiated with $3.0 \mathrm{kGy}$ dose had extended shelf-life up to 12 days however, Garcýa-Márquez et al., (2012a) reported that the shelf life of the irradiated pork loin was increased up to 20 days by using a dose of 2 $\mathrm{kGy}$. Moreover, the present study also showed that the number for microbial log cycle reduction in the pork salamis were relatively low when compared to Heath et al., (1990) who found that an electron beam irradiation dose as low as $1.0 \mathrm{kGy}$ showed 2 to $3 \mathrm{log}$ cycle reduction in the total number of aerobic organisms in broiler breast and thigh pieces. The Irradiation decimal reduction of bacteria in food depends on several factors, including water activity, food composition, irradiation or storage temperature, and presence of oxygen (Yimet al., 2017). Thus in the present study, the pork salami showed $1.79 ; 1.90$ and $1.90 \log$ cycle reduction in the TVC ofpork salamis irradiated at 3.0,3.5 and $4.5 \mathrm{kGy}$, respectively.

In the present study, there was a substantial reduction in the number of $S$. aureus which is in agreement with the results as reported by Klinger et al., (1986) who observed reduction of 2 logarithmic cycles in Staphylococcus populations in chicken carcasses irradiated with $4.5 \mathrm{kGy}$. Similar findings were observed by Thayer and Bond (1992) who reported that irradiation dose as low as 0.26 and $0.36 \mathrm{kGy}$ resulted in a marginal reduction of $S$. aureus in meat. Irradiation showed a substantial reduction in the gram-negative organism whereas gram positive still persisted and organisms like $S$. aureus predominated in 3 and $3.5 \mathrm{KGy}$ treated samples. Microorganisms express different tolerance levels towards specific doses of irradiation, gram positive bacteria display stronger resistance than gram negative bacteria (Lung et al., 2015). In contradictory to present observations Nouchpramool et al., (1985) reported that the dose of radiation of $3.0 \mathrm{KGy}$ was able to eliminate $S$. aureus in frozen shrimp. The dose of $2.5 \mathrm{KGy}$ was able to eliminate Staphylococcus aureus in smoked fish. However, Kolsarici and Kirimca (1995) verified that Staphylococcus were resistant to doses of irradiation up to $3.0 \mathrm{KGy}$ in chicken meat.

E. coli was detected only in non-irradiated (control) pork sausage samples. The average E. coli count $(\log \mathrm{cfu} / \mathrm{g})$ on 0 day in control sample of sausage was found to be $2.70 \pm 0.23$ which gradually increased to $3.33 \pm 0.14$ on $9^{\text {th }}$ day after which the sample were not analysed as they were marred. However, none of the irradiated pork sausage samples were found positive for E. coli. Banati et al., (1993) reported 4 logarithmic cycles reduction in Escherichia coli population in irradiated chicken meat at the dose rate of $2 \mathrm{kGy}$. Similarly, Lambert et al., (1992), Naik et al., (1994) and Diehl, (1995) reported that irradiated meat was completely free of Enterobacteriaceae for the entire storage (0-3

${ }^{0} \mathrm{C}$ ) period of four weeks. Among the most sensitive microorganisms to radiation are gram-negative rods, followed by grampositive cocci and rods, yeast, molds, fungal spores, aerobic and anaerobic spore formers irradiation had the greatest effect on Enterobacteriaceae.

Amongst all the control and irradiated pork sausage samples analysed for the presence of Salmonella spp. all the control pork sausage samples showed the presence of Salmonella spp. throughout the storage up to $9^{\text {th }}$ day. However, none of the irradiated samples at different doses showed the presence of 
Salmonella Spp. Similar findings were observed by Lewis et al., (2002) who reported the complete elimination of the Salmonella from the boneless skinless breast of chicken after electron beam irradiation with doses of 1.0 and $1.8 \mathrm{kGy}$. The findings of present study were in agreement with Thayer et al., (1990), Grant and Patterson (1992) and (Cabeza et al., 2009) who reported that dose of $0.53 \mathrm{KGy}$, $0.44 \mathrm{KGy}$ and $0.53 \mathrm{KGy}$ was effective in reducing Salmonella from mechanically deboned poultry, pork fermented sausages and dry cured ham, respectively. This might be due to Gram-negative bacteria are more radiosensitive than Gram-positive (Cambero et al., 2012).

All the control and irradiated pork sausage samples were analysed for B. cereus, Pseudomonas spp. and Listeria spp. after storage at refrigeration temperature. It was evident that none of the pork sausage samples as well as control samples were found to contain these organisms. Similar findings were noted by Shamsuzzaman et al., (1992) who reported that uninoculated chicken breasts, both raw and treated, were negative for Listeria spp. This could be due to Gramnegative bacteria are more radiosensitive than Gram-positive (Cambero et al., 2012).

The increasing trend in initial yeast and mold count $(\log \mathrm{cfu} / \mathrm{ml})$ was observed in control and irradiated pork sausage samples. The numbers increased with storage time and there was a significant $(\mathrm{p}<0.05)$ difference between the irradiation doses. The present study revealed that there was a reduction in the yeast and mold count which was in agreement with Ko et al., (2005) who reported reduction in the yeast and mold count in chicken breast after irradiation at the dose rate of 4 KGy while, Kim et al., (2012) reported that yeast and mold populations were not detected in pork jerky when irradiated using a dose of $4 \mathrm{KGy}$. Electron beam irradiation is an effective method for mold decontamination and sterilization. Moreover, in future it may replace conventional dry sterilization techniques; high dose EBI sterilization may allow energy saving compared to the conventional techniques (Stewart and Padalia, 2015).

Recent advances in electron beam technology have made this mode of sterilization a worthy competitor to the traditional gamma processing. Electron beam irradiation of pork sausage products resulted in a dose dependent decrease in the total viable counts and in reduction/elimination of pathogenic organisms. Electron beam irradiation was found more effective on gram-negative rods like Enterobacteriaceae, followed by grampositive cocci and rods, yeast, molds, fungal spores, aerobic and anaerobic spore formers. Therefore, this study shows that irradiation in conjunction with chilled storage inhibits microbial growth without compromising product safety. Thus, radiation processing could be used to the advantage of processors, retailers and consumers.

\section{Acknowledgements}

This work was supported by grants from Indian Council of Agricultural Research, New Delhi under "All India Co-Ordinated Research Project on Post-Harvest Engineering and Technology" implemented at Bombay Veterinary College, Mumbai centre.

\section{References}

Cabeza, M.C., I. Cambero, L. de la Hoz and J.A. Ordóñez 2007. Optimization of E-beam irradiation treatment to eliminate Listeria monocytogenes from ready-to-eat (RTE) cooked ham. Innovative food sci. and emerging tech.,8(2): 299-305. 
Cambero, M.I., Cabeza, M.C., R. Escudero, S. Manzano, I. Garcia-Marquez and R. Velasco 2012. Sanitation of selected ready-to- eat intermediate-moisture foods of animal origin by E-beam irradiation. Food-borne Pathogens and Dis.9:594-599.

Diehl, J.F. 1995. Chemical effects of ionizing radiation. Safety of Irradiated Foods. $2^{\text {nd }}$ Ed. New York: Marcel Dekker. 43-87.

García-Márquez, I., M.I. Cambero, J.A. Ordóñez, and M.C. Cabeza 2012. Shelf-life extension and sanitation of fresh pork loin by E-beam treatment. Journal of Food Protec., 75(12): 2179-2189.

Grant, I.R. and Patterson,M.F. 1991. Effect of irradiation and modified atmosphere packaging on the microbiological safety of minced pork stored under temperature abuse conditions. International J. food sci. and tech., 26(5): 521-533

Hammad, A.A.I., T.M. El-Mongy and A.K. Mabrouk. 2000. Shelf-life extension and improvement of the microbiological quality of fresh sausage by irradiation. Egyptian $J$. Radiation Sci. and Applicat.13(1): 5975.

Heath, J.L., S.L. Owens and S. Tesch 1990. Effects of high energy electron irradiation of chicken meat on Salmonella and aerobic plate count. Poult. Sci. 69:150-156.

IS 5887 1999. Methods for detection of bacteria responsible for food poisoning Part 3: General guidance on methods for the detection of Salmonella.

Kanatt, S.R., R., Chander, and A. Sharma 2005. Effect of radiation processing on the quality of chilled meat products. Meat sci., 69(2):269-275.
Kim, H.J., M. Kang and C. Jo, 2012. Combined effects of electron beam irradiation and addition of onion peel extracts and flavoring on microbial and sensorial quality of pork jerky. CNU J. Agric. Sci.,39: 341-347.

Klinger, I., V. Fuchs, D. Basker, B. J. Juven, M. Lapidot and E. Eisenberg. 1986. Irradiation of broiler chicken meat. Israel J. Vet. Med., 42(3): 181.

Ko, J.K., Y.H. Ma and K.B. Song.2005. Effect of electron beam irradiation on the microbial growth and qualities of chicken breast. J.of the Korean Soc. for Appl. Biol. Chem., 48(2):120-127.

Kolsarici, N. and G. Kirimca 1995. Effect of radurization on microbiological, chemical and sensorial properties of chicken meats. J. Gida.,20(2): 67-73.

Lambert, A.D., J.P. Smith and K.L. Dodds 1992. Physical, chemical and sensory changes in irradiated fresh pork packaged in modified atmosphere. $J$. Food Sci.,57(6): 1294-1299.

Lewis, S.J., A. Velasquez and, V. Cuppett 2002. Effect of electron beam irradiation on poultry meat safety and quality. Poultry sci. 81(6):896-903.

Lim, D.G., K.H. Seol, H.J. Jeon, C. Jo and M. Lee 2008. Application of electronbeam irradiation combined with antioxidants for fermented sausage and its quality characteristic. Radiation Physi. and Chem., 77(6): 818-824.

Lung, H. M., Y. C. Cheng, Y. H. Chang, H. W. Huang, B. B. Yang and C. Y. Wang (2015) Microbial decontamination of food by electron beam irradiation. Trends in Food Sci. and Tech.,44(1): 66-78.

Naik, G.N., P. Paul, S.P. Chawla, A.T. Sherikar and P.M. Nair 1994. Influence of low dose irradiation on the quality of fresh buffalo meat 
stored at $0-3^{0}$ C. Meat sci.,38(2): 307-313.

Niemand, J. G., H. J. Vanderlinde and W. H. Holzapfel 1981.Radurization of prime beef cuts. J. Food Prot., 44: 677-681.

Nouchpramool, K., S. Pungsilpa and P. Adulyatham 1985. Improvement of bacteriological quality of frozen shrimp by gamma radiation (No. OAEP--1-120). Office of Atomic Energy for Peace.

Shamsuzzaman, K., N. Chuaqui-Offermanns, L. Lucht, T. McDougall and J. Borsa 1992. Microbiological and other characteristics of chicken breast meat following electron-beam and sousvide treatments. J. Food Protect, 55(7): 528-533.

Shin, M.H., J.W. Lee, Y.M. Yoon, J.H. Kim, B.G. Moon, J.H. Kim and B.S. Song 2014. Comparison of quality of bologna sausage manufactured by electron beam or X-ray irradiated ground pork. Korean J. Food Sci. of Ani. Resour., 34(4): 464.

Speck, M.L. 1984. Compendium of method of microbiological examination of foods. American Public Health Association, Washington DC.

Thayer, D.W. and Boyd G. 1991. Effect of ionizing radiation dose, temperature and atmosphere on the survival of Salmonella typhimurium in sterile, mechanically deboned chicken meat. Poultry sci., 70(2): 381-388.

Yim, D., G. Jo, C. H. C. Kim, K.S. Seo and K.C. Nam 2016. Application of Electron-Beam Irradiation Combined with Aging for Improvement of Microbiological and Physicochemical Quality of Beef Loin. Korean J. food sci. of animal resour, 36(2): 213-215.

\section{How to cite this article:}

Deepika, P., R.J. Zende, D.P. Kshirsagar, V.S. Lande, V.M. Vaidya, R.N. Waghamare, R.P. Todankar and Shirke, A.H. 2017. Effects of Electron Beam Irradiation on Microbial Quality of Pork Sausage Stored at Refrigeration Temperature. Int.J.Curr.Microbiol.App.Sci. 6(11): 39783987. doi: https://doi.org/10.20546/ijcmas.2017.611.466 